mediastudies.press • Social Media \& the Self: An Open Reader

\title{
The Theory and History of Authenticity
}

Charles Lindholm 1

${ }^{1}$ Boston University

Published on: Jan 01, 2007

License: Creative Commons Attribution-NonCommercial 4.0 International License ( $\underline{C C-B Y-}$ NC 4.0). 


\section{The Social Origins of Authenticity}

WHAT ACTUAL CIRCUMSTANCES favored the rise of authenticity as a vital goal in today's society? Lionel Trilling attempted to answer this question when he described the growth of authenticity out of the simpler and more modest virtue of sincerity, which itself arose in response to the momentous shift out of feudalism. 1 According to Trilling, the concept of sincerity first emerged as a precursor to authenticity in the 16 th century as a result of the gradual breakup of the face-to-face relationships of traditional European society. As was the case in many other pre-modern traditional societies around the world, the highly personalized universe of Medieval Europe was held together by a taken-for-granted social order that provided its members with secure positions in a divinely sanctioned hierarchy. Local authorities served church and state, and were served in turn by their vassals. The family replicated this order, with the father exercising a sacralized authority. This stratified and sanctified worldview validated the daily lives of the faithful. For most of those living in this cosmically ordained system, there was little or no travel away from their locality, and little or no social mobility within it. Under these circumstances individuals were constrained by the obligations entailed in their predestined social roles. What mattered was not personal sincerity and purity of intent, but only whether persons were able to live up to their obligations to the neighbors and kinsmen they had known and who had known them all their lives.

This stable world was transformed utterly by the breakup of the feudal system and the massive movement of individuals out of the countryside and into mixed urban environments. Henceforth, people were no longer quite sure where they belonged, what their futures held for them, or who their neighbors were. They had begun the irreversible plunge into modernity, which can be succinctly defined as the condition of living among strangers. In this new, desacralized and unpredictable environment it became possible for some ambitious men and women to break out of their prescribed roles and pursue secular dreams of wealth, power, and fame. But the pleasures and possibilities of social mobility coincided with feelings of alienation and meaninglessness, as well as the potential for guile and deceit. Former inferiors could now pretend to be better than they actually were; origins could be hidden and high status positions claimed without any legitimate basis; neighbors could cheat and betray one another and vanish into the anonymous urban wilderness. It is not surprising that the original definition of the villain was the dissembler, a lowly person who rises by cunning. $\underline{2}$ In this ambiguous milieu it is also not surprising that sincerity, 
doing what one says one will do, became a desired trait. The erosion of a sacred hierarchy, the fragmentation of roles and the sense of a loss of significance were met by the sincere person's reliance on inner integrity to establish trusting and meaningful relationships. As Polonius advises his son: "To Thine own self be true and it follows as the night the day that thou canst not be false to any man."

This shift was supported by the dogmas of a newly rising Protestant bourgeoisie who had begun to transform the moral climate of Europe. The Protestants asserted that all persons are ultimately responsible for their own salvation. According to their doctrine, no one could intervene between the worshipper and God; no priest could interpret the confessions of the faithful and absolve them of their sins or sell them guarantees against damnation. Instead, the members of the congregation had to become worthy of redemption on their own. This could only be accomplished by scrutinizing their souls to uncover and root out any evil impulses. Since they were required to practice selfinterrogation and purification, the Protestant faithful tended to became urgently concerned about their own motivations: for them, it was not enough to act morally, they now had to be certain that the intent behind the act was also wholesome. As a result, sincerity became a defining virtue among this vanguard population.

The rise of sincerity also correlated with the radical egalitarianism that was practiced and preached by Protestants, who not only defined themselves in opposition to the hierarchies of the Catholic church, but also against the formalities of a remote and increasingly illegitimate courtly society. Instead of an ostentatious display of silks and jewels, they self-consciously wore plain clothing and appeared without adornment, revealing themselves in public 'as they really were.' Similarly, they made a practice of simple speech that did not employ any of the flattery and rhetorical flourishes of the gentry. But the requirements of modesty and sincerity had paradoxical consequences.

The first was the ambiguity of representation. How could persons thrown back on their own interpretations of themselves and their duties be certain that the appearance of sincerity was not actually the result of self-delusion and pride? Couldn't the unpretentious man actually be sinfully proud of his modesty, couldn't the believer persuaded of his sincerity actually be the worst of hypocrites, capable of lying even to himself? The second was the relation between the perception of inner truth and the demands of the social order. Couldn't being true to one's own intuition of right and wrong be more important than conforming to what is required by society?

Because their doctrine considered all human beings to be spiritual equals in the eyes of God, the most extreme Protestants even believed they could and should speak to 
aristocrats without honorifics or etiquette. That this might lead to dire consequences did not matter to them; they would be rewarded in heaven. Their critical attitude toward authority easily spread to self-questioning. How are we to know what we are really like, and what God really demands of us? Many Protestants tormented themselves with internal debates about these knotty matters of conscience, selfdeception, and duty, as we know from the diaries and autobiographies that proliferated as an outlet for their spiritual anxieties. $\underline{3}$ As a result, they were passionately concerned to discover an ultimate and absolute truth, outside of social norms and emotionally compelling. This moved them away from the social virtue of sincerity and toward the more solipsistic goal of finding a guiding inner light-that is, of achieving authenticity. $[\ldots]$

The gradual triumph of capitalism and the predominance of wage labor provided another impetus toward development of the modern ideal of authenticity. In the old system, a worker's inner feelings and sense of self were irrelevant, since each person was locked into an occupation that would last a lifetime. It was enough that the role was enacted properly. But when work in the open market was no longer hereditary or connected to any larger meaning system, labor began to lose its capacity to define identity. Instead there was increasing alienation from work that seemed meaningless and, worse, destructive of the worker's eternal soul. Revulsion was especially directed toward the obligation to act obsequiously in order to please employers. Previously, subservience was part of a larger cosmic order of deference; now it stood athwart the new ideal of equality. $\underline{4}$ Workers had become capable of imagining something better for themselves, but they also knew they could be dismissed for expressing resistance; as a result, for many their occupation was no longer a calling demanded by God, but rather became the enforced imposition of unwanted inferiority by an increasingly alien and antagonistic authority.

As a result of all these factors, the early Protestant distaste for aristocratic artifice was easily extended to become a generalized contempt for role-playing in general. As one writer put it: "Born Originals, how comes it to pass that we die Copies?" $\underline{5}$ To balance out the perceived distortion and repression of newly discovered individual personalities and universal souls in the competitive open marketplace, people began to believe that their common humanity demanded free sharing of genuine (that is, authentic) feelings when among intimates. [...]

The social consequences of the new emphasis on personal authenticity were profound. Protestants throughout Europe began to declare that they were no longer obliged to 
follow whatever rules were handed down from above; instead, one's duty was to make a personal judgment as to whether those rules were moral and equitable. These judgments could be made by referring to one's inner light-that is, to the authentic moral truth emanating from within, and not by obedience to the conventions attached to social roles. Soon enough, this critical attitude spread beyond the church. In the same fashion as a Protestant church member had a duty to leave the congregation and find another more in tune with his or her values, thinking men and women in Europe and later in America began to make personal decisions as to whether the state deserved their loyalty. If not, the citizen had an obligation to stand up in opposition to the injustice and, in the extreme case of France, to overturn the state and establish a new one that would offer them an authentic community, envisioned in a way not very different from a covenanted Protestant congregation. [...]

\section{The Literature of Authenticity}

The rise of authenticity as a value was echoed in European literature. According to Trilling, the first to write about personal authenticity was Molière (1622-1673), who followed his satire Tartuffe with The Misanthrope, a comedy about the futile attempts of its hero Alceste to impose absolute standards of truthfulness on French court society. $\underline{6}$ The two plays are illustrations of two very different ways of understanding the world. Tartuffe is a fraud and flatterer who has no delusions about the selfaggrandizing nature of his trickery and deceit. For him, a sin is not a sin if it is not witnessed. In contrast, Alceste asserts that "a man should be a man, and let his speech at every turn reveal his heart to each; his own true self should speak; our sentiments should never hide beneath vain compliments." $\underline{7}$ Molière portrays Alceste as a ridiculous figure: a self-righteous narcissist whose unrealistic demands lead him to isolation and disaster. He is "the new hypocrite [who] simply adjusts his conscience by ascribing noble, disinterested, and altruistic intentions to all his behavior. He is the sole instructor of his own conscience."푸

Molière's satirical treatment of Alceste shows that personal authenticity, especially in its guise as authenticity of content, had not yet become a cultural ideal in the 17th century, though its outlines were known. But soon authentic protagonists began to be seen in a more positive light. Written in 1761, Denis Diderot's dialogue between himself (the philosopher) and Rameau's nephew marks a crucial step in this evolution. The self-aware hero, known only through his relationship with the famous composer, $\underline{9}$ is Protean, emotional, witty, and creative; Diderot (1713-1784) likens him to a grain of 
fermenting yeast restoring individuality and creativity to a stultified society. But unlike the rigidly self-righteous nobleman Alceste, Rameau's nephew is an outsider, a con man, a liar, and a toady who willingly demeans himself for the entertainment of others. This is necessary, he says, because the world is composed of the powerful and the weak. The latter must cringe and crawl, playing the servile roles required of them. Even the courtier must fawn and simper before the king. Rameau's nephew, because he is powerless, must do the same, but unlike the rest, he does not delude himself about reality or his position. "I'm never false if my interest is to be true and never true if my interest is to be false." And, unlike Alceste, he is able to live in the world, while at the same time seeing it for what it is. $\underline{10}$

In his great book The Phenomenology of Mind, the romantic philosopher G. W. F. Hegel (1770-1831) depicted Rameau's nephew as the first of a new type of radically authentic individuals who could no longer identify with society and instead embrace fragmentation and marginalization, "rending and tearing everything" and pouring contemptuous scorn on the lifeless and fraudulent world of the bourgeoisie.

Shameless, perverted, and "conscious of its own distraught and torn condition," 11 this figure is the prototype for Dostoevsky's underground man, Sartre's Saint Genet, and the other corrosively obscene, marginal, criminal and deviant anti-heroes of the modern age whose very existences repudiate a milieu that is taken to be hypocritical and oppressive. As Marshall Berman puts it, "The search for authenticity, nearly everywhere we find it in modern times, is bound up with a radical rejection of things as they are." $\underline{12}$

However, in his anxiety to portray Rameau's nephew as a paragon of revolutionary contempt for the status quo, Hegel ignored some of aspects of his character that would be influential to later romantic thought. In particular, the nephew was an enthusiastic aesthete and a would-be artist who idealized natural spontaneous feeling in music and in the soul. He tells Diderot "our passions have to be strong. The tenderness of the musician and the poet must be extreme ... We want it more energetic, less mannered, more genuine." 13 As a proponent of heartfelt feeling, Rameau's nephew is a direct forerunner of another prototypical figure in the literature of authenticity, i.e., Goethe's (1749-1832) most famous literary creation: young Werther, the wandering sketch artist and doomed lover. Like Rameau's nephew, Werther too sees through the restrictive constraints of bourgeois society. "Why does the stream of genius so seldom break out as a torrent, with roaring high waves, and shake your awed soul? - dear friends, because there are cool and composed gentlemen living on both banks, whose garden 
houses, tulip beds and cabbage fields would be devastated if they had not in good time known how to meet the threatening danger by building dams and ditches" (emphasis in the original). He too is a seeker after natural feeling in art, and he too defies social conventions.

But where Rameau's indomitable nephew refutes the hypocrisy of the world with his caustic laughter, Werther-a more sensitive and sentimental soul-finds solace in his heart, "which is my only pride, and the fountainhead of all-all strength, happiness and misery. Anyone can know what I know. My heart alone is my own." 14 Unhappily, his feckless heart leads him into a hopeless love affair. When that fails, he descends into depression and kills himself, inspiring a rash of real-life suicides throughout Europe. His is an early example of the secret affinity between authenticity and morbidity that was to be so characteristic of later German philosophy.

Goethe's attitude toward his young hero was ambiguous; while he too favored feeling, he feared its excesses, and the final stark image of Werther's brains spilled across the floor is a chilling warning against viewing the world through the lens of one's emotions. Hegel was even more scathing toward what he regarded as a spectacularly destructive form of romantic consciousness, which he called "the law of the heart." This is the notion that one's own true feelings provide an adequate basis for judgment and action. Such a belief must, Hegel argued, lead to the sense that the external world, insofar as it does not conform to one's desires, is alien and hateful. Trying to universalize one's own feelings inevitably leads to "consciousness gone crazy ... The heart-throb for the welfare of mankind passes therefore into the rage of frantic selfconceit," as every consciousness seeks to impose its heart's ambitions upon all others. $\frac{15}{}$

Jean-Jacques Rousseau (1712-1778) was one of the figures Hegel had in mind when he castigated the romantic faith in the law of the heart. Rousseau, who believed that Alceste had been quite correct to demand absolute honesty from the world, and from himself, became the first writer to present the reading public with a completely positive picture of an authentic individual who lives wholly according to his own emotional reality regardless of the opinions of others. It is no accident that this exemplary figure was Rousseau himself. In his celebrated autobiography he shamelessly revealed himself as self-serving, cowardly, obsequious, masochistic, sexually deviant (he was aroused by being spanked), and paranoid. As he proudly proclaims, "let the numberless legion of my fellow men gather round me and hear my confessions. Let them groan at my depravities and blush for my misdeeds. But let each 
one of them reveal his heart at the foot of thy throne with equal sincerity, and may any man who dares say, 'I was a better man than he." $\underline{16}$

Claiming superiority through the very act of exposing his worst defects heralded a new ideal of exploring and revealing one's essential nature-being true to oneself even while flying in the face of the moral standards of society. For Rousseau, as for his Calvinist forefathers, so long as a person heeds the prompting of his or her inner being, the judgments of others count for nothing. He concludes, "To live is to make use of our organs, our selves, our faculties, every part of ourselves which gives us the feeling of our own existence. The man who has lived the longest is not he who has passed the greatest number of years, but he who has felt life." $\underline{17}$

\section{The Philosophy of Authenticity}

Rousseau spent his career trying to understand the relationship between 'the sentiment of being' and the rules of civilization. As he famously remarked in the first page of The Social Contract, "Man was born free, and everywhere he is in chains." 18 According to Rousseau's extremely influential anthropological theory of human origins, this degradation occurred because the growth of civilization has destroyed our original natures, which were motivated only by amour de soi (self-love); referring only to ourselves, we were without greed or ambition. Only with the gradual development of the division of labor, and the differences in wealth and property that resulted, did humans learn to covet our neighbor's possessions and to puff ourselves up in hopes of exciting envy. Motivated by amour propré (vanity), we sought prestige and status at the expense of others and became slaves of culture and tradition, living lives that are just play-acting. We are now only capable of experiencing ourselves when reflected in the eyes of others. If admired, we are proud; if held in contempt, we despise ourselves. Civilization has robbed humans of our independence and deformed our true natures; it has made us slaves of power and imitators of fashion. Not only are we enchained; we have even grown to love our chains, and to embrace the social world that has destroyed our genuine being. Under these conditions, "The majority of men are quite unlike themselves, and often seem to transform themselves into different men." $\underline{19}$

For Rousseau, some remnants of the original authentic character of humanity could still be found in simpler cultures, which are closer to the pure state of nature. As we will see, his nostalgia for the primitive and the essential was manifested in later theories of tribal purity, nationalism and ethnic pride. Equally influential was his belief that children were repositories of humanity's fundamental innocence, which finds its 
modern expression in therapeutic injunctions to find authenticity by 'getting in touch with the inner child.' Finally, Rousseau also believed that certain receptive souls, such as his own, were more attuned to hear the authentic promptings of the heart. They could shut out daily reality and discover fulfillment through cultivation of reverie and other trance-like states of consciousness. "As long as this state lasts, we can call ourselves happy, not with a poor, incomplete and relative happiness such as we find in the pleasures of life, but with a sufficient, complete and perfect happiness which leaves no emptiness to be filled in the soul." $\underline{20}$ In this passage, Rousseau prefigured the use of meditation, drug use, and other aids to transcending ordinary consciousness as aids in the quest for authenticity.

Rousseau's theories about authenticity met an enthusiastic response in Germany. There Herder, Schiller, Hegel, Schopenhauer, Goethe and others prepared the ground for a new vision of human existence proposed by Friedrich Nietzsche (1844-1900). Nietzsche detested the dull and predictable bourgeois world inhabited by "natures that are denied the true reaction, that of deeds, and compensate themselves with an imaginary revenge." According to Nietzsche, the predominant Christian slave morality, motivated by a psychology of ressentiment against the strong and the vital, hides its baseness behind guilty conformity and soulless respectability. Things become worse with modernity, which diffuses primal experience into a plethora of 'objective' abstractions, a stifling of the instincts, a debilitating sense of being "a strolling spectator" in life, and a feeble nostalgia for the passions of a lost past. Under these dire circumstances, "no one dares appear as he is, but masks himself as a cultivated man, as a scholar, as a poet, as a politician." Redemption from this falsity cannot come from religion, since "nothing turns out to be divine any longer unless it be error, blindness, lies." $\underline{21}$ Rather, the seeker must tear away the veils of convention, morality and faith. "Let him follow his conscience, which calls out to him: 'Be yourself! What you're doing, supposing, desiring now-that's not you at all.'" Those few who have achieved "productive uniqueness" are transformed, and shine with a "strange radiance." 22 They are "the new, the unique, the incomparable, those who give themselves their own law, those who create themselves." $\underline{23}$ [...]

[A] popular native-grown cult of authenticity was already well developed in the United States as part of what William James (1842-1910) termed the faith of the once born or healthy minded - a belief system he prophesied would be the religion of the future. Instead of concerning itself with the irreversible reality of human suffering, as existentialism and its continental predecessors had done, James notes that the 
American once born faith is optimistic and hopeful. Pain and misery are illusions that individual human beings, by dint of spiritual discipline, can conquer. This can be accomplished by tearing away the restrictive veils of reason, culture, and convention that separate the individual human soul from the sacred core of the self, as intuited by the heart. Purified, the believers can then touch the primal source of being and experience the expansive joys of cosmic unity and personal redemption. $\underline{24}$

Ralph Waldo Emerson (1803-1882) put the self-referential and spiritual aspect of this particularly American brand of authenticity best in his famous essay "Self-Reliance." As he writes: "I must be myself. I cannot break myself any longer for you, or you. If you can love me for what I am, we shall be the happier. If you cannot, I will still seek to deserve that you should. I will not hide my tastes or aversions. I will so trust that what is deep is holy, that I will do strongly before the sun and moon whatever only rejoices me, and the heart appoints." For Emerson, realizing and expressing one's own inner truth was a priority above and beyond conventional notions of good and evil. "No law can be sacred to me but that of my nature. Good and bad are but names very readily transferable to that or this; the only right is what is after my constitution; the only wrong what is against it." $\underline{25}$

James' prediction that the pursuit of personal authenticity would dominate modern American spirituality can easily be verified by entering any bookstore. The shelves are weighted down with advice from New Age gurus and therapists who instruct seekers how to discipline themselves in order to unleash their inner child, reach a higher spiritual plateau, find a power source, heal themselves, free the thin person within the fat one, or play better tennis. What is characteristic of these self-help books is that the techniques offered are not simply means to achieve a particular end, but rather are supposed to help the readers get in touch with their authentic selves. Having achieved this ultimate goal, clarity of thought, happiness in relationships, success in business, a cure for angina, a slimmer figure, or a better backhand will necessarily follow. While existentialists suffer in the alienating world, American once-born enthusiasts succeed in conquering it.

The burgeoning popularity of an ethic of authenticity appalled a number of American cultural critics such as Allan Bloom, Daniel Bell and Christopher Lasch, who decried it as pure hedonistic narcissism masquerading as philosophy. Weak, self-indulgent, and incapable of moral action or even of defending their own beliefs in any coherent fashion, the New Age propagandists were destroying the moral fiber of the nation in favor of feeble relativism and thoughtless self-indulgence. In response, Charles Taylor 
mounted a spirited defense of authenticity rightly understood. He claimed that even the proponents of authenticity had been misled by an overemphasis on self-realization, and so had neglected the moral and social aspects of living an authentic life. "Selfchoice as an ideal makes sense only because some issues are more significant than others." The most important and motivating issues, Taylor argued, arise in a modern context where positions are not ascribed, and people must prove their value to one another. When identity is generated, not given, persons must discover and ratify who they really are through dialogue; the authentic person cannot exist alone, but must win the recognition and respect of others. He concludes on a hopeful note: "perhaps the loss of a sense of belonging through a publicly defined order needs to be compensated by a stronger, more inner sense of linkage."르

Taylor rightly draws our attention to the social aspects of the pursuit of personal authenticity, but neither he nor other modern theorists devote much (or any) space to exploration of the implications and consequences of the pursuit of collective authenticity. Perhaps this is because the rise of individualism has been the most striking aspect of modernity, or perhaps it is because collective authenticity, as manifested in nationalism, has a bad reputation, since the exemplar case is Nazi Germany. Whatever the cause, it is remarkable that the recent philosophical literature on authenticity has ignored collectives. This despite the fact that Romantic thinkers, Herder above all, believed that nations had their own essences, which needed to be preserved and expressed in the lives and works of the citizenry for them to be true to themselves. This lacuna is correlated with another absence. The emphasis in modern thought has consistently been on authenticity as correspondence-on being what one is. But [...] authenticity has another meaning as well. That is, the authenticity of origin, of genealogy, of roots.

Certainly this overlaps with the notion of correspondence, but it points in a different direction, away from the self, and toward history, tradition, and ancestry, all of which are associated with collective identities of nation, tribe, and race. Finally, none of the critics or theorists of authenticity have had much to say about the way authenticity is actually pursued. $\underline{27}$

\section{ABRIDGMENT}

"The Theory and History of Authenticity." (Charles Lindholm, unpublished manuscript book chapter related to the book Culture and Authenticity, Basil Blackwell, 2007) 
OPENLY LICENSED

\section{Footnotes}

1. Trilling, Sincerity and Authenticity (Cambridge: Harvard University Press, 1974). For an exegesis of many of the works discussed by Trilling, see Marshall Berman, The Politics of Authenticity: Radical Individualism and the Emergence of Modern Society (New York: Atheneum, 1970). My historical understanding of the rise of authenticity has also been influenced by Charles Taylor, The Ethics of Authenticity (Cambridge: Harvard University Press, 1991), and Charles Taylor, Sources of the Self (Cambridge: Harvard University Press, 1989).

2. For a history of these developments see Norbert Elias, The Civilizing Process: The Development of Manners (New York: Urizen, 1978), original publication 1939.

3. The increasing prevalence of self-portraits, mirrors, and autobiography during the 16 th and 17th century are all taken by Trilling as evidence of the rise of sincerity and authenticity as new virtues. $\doteq$

4. Jean-Jacques Rousseau was the most articulate spokesman for this new form of alienation. He had worked as a servant, and his hatred of inequity and demeaning labor permeates all of his writings. See James Miller, Rousseau: Dreamer of Democracy (New Haven: Yale University Press, 1984).

5. Edward Young, quoted in Trilling, Sincerity and Authenticity, 93.

6. Molière, like the other writers to whom I will refer in this chapter, did not actually use the term 'authenticity' in their works. However, the content shows that what I have defined as authenticity was foremost on their minds. $\triangleq$

7. Molière, The Misanthrope, trans. Donald Frame (New York: New American Library, 1968): 25, 78, 69.

8. Judith Shklar, Ordinary Vices (Cambridge: Harvard University Press, 1984), 58. 9. His actual name, never mentioned in the dialogue, is Jean-Francois Rameau. $ヒ$ 10. Diderot, Rameau's Nephew and First Satire, trans. Margaret Mouldon (Oxford: Oxford University Press, 2009), original publication 1805. 11. Hegel, The Phenomenology of Mind (New York: Harper and Row, 1967): 542, 546, original publication 1807. 
12. Berman, Politics of Authenticity, xix. $\_$

13. Diderot, Rameau's Nephew, 70. $\triangleq$

14. Goethe, Sorrows of Young Werther (New York: Vintage, 1990): 15, 97, original publication 1774. Goethe translated "Rameau's Nephew” into German, rescuing it from unpublished obscurity in France, and drawing it to Hegel's attention. For an illuminating study of the manner Diderot's essay effected German philosophy, see James Schmidt, “The Fool's Truth: Diderot, Goethe, and Hegel," History of Ideas 57, no. 4 (1996).

15. Hegel, Phenomenology of Mind, 396, 397.

16. Rousseau, The Confessions of J. J. Rousseau (Baltimore: Penguin, 1951). Quoted in Trilling, Sincerity and Authenticity, 58.

17. Quoted in Berman, Politics of Authenticity. $\leftrightarrows$

18. Rousseau, "The Social Contract," in The Social Contract and the Discourse on the Origin and Foundations of Inequality Among Mankind, ed. Lester G. Crocker, ed., 5-150 (New York: Washington Square Press, 1967), original publication $1762 \leftrightharpoons$

19. Rousseau, "The Social Contract," 7.

20. Rousseau, Reveries of the Solitary Walker (London: Penguin, 1979), 88, original publication 1782.

21. Nietzsche, On the Genealogy of Morals (New York: Vintage, 1969), 36, 152, original publication 1886.

22. Nietzsche, Untimely Meditations, trans. R. J. Hollingdale (Cambridge:

Cambridge University Press, 1997), 83, 84, 287-8, 306. For more on Nietzsche's concept of originality and genius, see Werner Hamacher, “'Disgregation of the Will': Nietzsche on the Individual and Individuality," in Reconstructing Individualism: Autonomy, Individuality, and the Self in Western Thought, ed. Thomas C. Heller, Morton Sosna, and David E. Wllbery, 106-39 (Stanford: Stanford University Press, 1986).

23. Nietzsche, The Gay Science (New York: Vintage Books, 1974), 335, original publication 1882. Note that Nietzsche did not believe self-creation and the realization of authentic agency could occur in a vacuum. Extremely conscious of the 
conditioning authority of history, language, and culture, he never fell into the romantic fallacy of the 'law of the heart' so decried by Hegel. For more, see Mark Warren, "Nietzsche's Concept of Ideology," Theory and Society 13, no. $4 . \pm$

24. James shared the once-born faith that the nonrational and expressive are at the core of human experience. In his great book The Varieties of Religious Experience he argued that the study of psychology had to go beyond empiricism and embrace emotion, intuition and subjectivity if it was ever to hope to understand human motivation. James practiced what he preached, and put emotional expressivity first in his own life. As he once said, for him "every gush of feeling should be followed by adequate action." Quoted in Louis Menand, The Metaphysical Club: A Story of Ideas in America (New York: Farrar, Strauss and Giroux, 2001), 77.

25. Emerson, "Self-Reliance," in Selected Writings of Emerson, ed. Brooks Atkinson, 145-69 (New York: Modern Library, 1950), original publication 1841. As Theodor Adorno comments, "In the name of contemporary authenticity even a torturer could put in all sorts of claims for compensation, to the extent that he was simply a true torturer." Adorno, The Jargon of Authenticity (Evanston: Northwestern University Press, 1973), 125.

26. Taylor, Ethics of Authenticity, 39, 91. $\Perp$

27. Taylor's brilliant book Sources of the Self (1989) provides an exhaustive overview of the philosophical history of the rise of personal authenticity, but does not rely on case histories to establish the way authenticity has actually been sought. $\boxminus$ 